(c) Elsevier/INRA

Original article

\title{
Genetic profiles from coat genes of natural Balearic cat populations: an eastern Mediterranean and North-African origin
}

\author{
M Ruiz-Garcia ${ }^{1,2}$ \\ 1 Instituto de Genetica, Universidad de Los Andes, \\ Calle 18, Carrena 1E, Bogota DC, Colombia; \\ ${ }^{2}$ CIGEEM Avd Virgen Montserrat $2076^{\circ} 1^{a}$. Barcelona 08026, Spain
}

(Received 6 November 1991; accepted 6 August 1993)

Summary - A detailed study of 7 cat populations (Felis silvestris catus) in the 3 principal Balearic islands has been carried out. These populations are Mahon (474 cats), Villacarlos (226 cats), Mercadal and Alayor (104 cats) and Ciudadela (510 cats) in Minorca, Palma Majorca ( 475 cats) in Majorca and Ibiza city (210 cats) and San Antonio (63 cats) in Ibiza. The gene frequencies derived from the phenotypic frequencies of a number of loci coding for coat colour and pattern, hair length and one skeleton anomaly were studied with the following implied mutant allele: $O$ (Orange; sex-linked allele); $a$ (Non-agouti); $t^{b}$ (Blotched tabby); $d$ (Dilution); $l$ (Long hair); $S$ (White spotting); $W$ (Dominant white); $c^{s}$ (Siamese); and $M$ (Manx). The range of frequency values for each of the loci studied is the following: $O: 0.16-0.30 ; a: 0.72-0.87 ; t^{b}: 0.0-0.35 ; d: 0.14-0.44 ; l: 0.0-0.27 ; S: 0.14-0.30 ; W: 0.0-$ $0.017 ; c^{s}: 0.12-0.31 ; M: 0.0-0.026$. In some populations in Minorca a significant excess of homozygotes was detected for the $O$ locus which might be due to the influence of some evolutionary agent. Though the genetic heterogeneity of the Balearic cat populations is substantially lower than that observed for other island mammals and the theoretical gene flow between these Balearic cat populations is noticeably stronger than that observed for other populations of mammals in these islands as well as in other islands, there is a statistically significant genetic heterogeneity between most of the loci studied and between the genetic profiles of the 7 cat populations. Some alleles $\left(d, S, W\right.$ and $\left.t^{b}\right)$ even show a clinal disposition. An analysis of the contribution of each locus to the gene diversity observed between the Iberian and Balearic cat populations shows that the largest part of this diversity is due to the $t^{b}$ allele. Generally speaking, all the genetic profiles analyzed show stronger genetic influences of eastern Mediterranean and North-African cat populations than of western European cat populations. However, of the 7 cat populations studied, that of Palma shows a slightly stronger influence of western European cat populations while the central and eastern populations of Minorca (Mahon, Villacarlos and particularly Mercadal and Alayor) seem to have followed a characteristically different evolutionary path caused by founder effect, gene drift and/or different gene flow from other places around 
the Mediterranean sea which have not yet been thoroughly studied. The possible origin of other species of mammals and the historical and commercial movements of the human beings in these islands might be parallel to the model proposed for the cat populations of the Balearic islands.

cat / population genetics / coat colour genes / genetic heterogeneity / gene flow

Résumé - Profils génétiques de populations naturelles de chats des Baléares sur la base de gènes de pelage : une provenance de Méditerranée orientale et d'Afrique du Nord. Une étude détaillée de 7 populations de chats (Felis silvestris catus) a été réalisée dans les 3 principales îles Baléares. Ces populations sont Mahon (474 chats), Villacarlos (226 chats), Mercadal et Alayor (104 chats) et Ciudadela (510 chats) à Minorque, Palma de Majorque (475 chats) à Majorque et Ibiza-ville (210 chats) et San Antonio (63 chats) à Ibiza. Les fréquences géniques dérivées des fréquences phénotypiques de quelques loci codant pour la couleur et le dessin de la robe, la longueur du poil et une anomalie squelettique ont été étudiées pour les allèles mutés suivants: $O$ (orange: allèle lié au sexe), a (Non Agouti), $t^{b}$ (Moucheté tacheté), d (Dilution), l (Long poil), $S$ (Tacheté blanc), $W$ (Blanc dominant), $c^{s}$ (Siamois) et $M$ (Manx). L'étendue de variation des fréquences géniques est la suivante: $0: 0,16-0,30 ; a: 0,72-0,87 ; t^{b}: 0,0-0,35 ; d$ : $0,14-0,44 ; l: 0,0-0,27 ; S: 0,14-0,30 ; W: 0,0-0,017 ; c^{s}: 0,12-0,31 ; M: 0,0-0,026$. Chez certaines populations de Minorque, un excès significatif d'homozygotes a été détecté au locus $O$ dî à l'influence d'un facteur sélectif. Bien que l'hétérogénéité génétique des chats des Baléares soit notablement inférieure à celle observée chez d'autres Mammifères îliens et que le flux génique théorique entre ces populations félines des Baléares soit notablement plus fort que ce qui est observé pour d'autres populations de Mammifères de ces îles et d'autres îles, il existe une hétérogénéité génétique statistiquement. significative entre la plupart des locus et entre les profils génétiques des 7 populations. Quelques allèles (d, $S, W$ et $t^{b}$ ) manifestent même une tendance clinale. L'analyse de la contribution de chaque locus à la diversité génétique observée entre les chats de l'Espagne et des Baléares montre que la plus grande part de cette diversité est due à l'allèle $t^{b}$. D'une manière générale, tous les profils génétiques analysés montrent des influences génétiques plus fortes des populations de chats de Méditerranée orientale et d'Afrique du Nord que de celles d'Europe occidentale. Mais parmi les 7 populations de chats étudiées, celle de Palma montre une influence légèrement plus forte des populations d'Europe occidentale, alors que les populations centrales et orientales de Minorque (Mahon, Villacarlos et particulièrement Mercadal et Alayor) semblent avoir suivi une évolution différente marquée par un effet fondateur, une dérive génétique et/ou des flux géniques différentiels à partir d'autres localités autour de la Méditerranée qui n'ont pas encore été étudiés d'une manière précise. Les origines possibles d'autres espèces de Mammifères et les mouvements humains dans ces îles pourraient être parallèles au modèle proposé pour les chats des îles Baléares.

chat / génétique des populations / gène de coloration / hétérogénéité génétique / flux génique

\section{INTRODUCTION}

More than 100 studies on the frequencies of alleles at loci that affect the fur of cats in more than 300 populations throughout the world have been carried out since Searle (1949) first studied the cat population in London. However, the lack 
of facts about the Iberian Peninsula and the Balearic islands has been remarkable until the last 3 or $4 \mathrm{yr}$. This study is an effort to provide these genetic data for the Balearic cat populations. In this work, we use the following plan: a) observe the individual existence of genetic heterogeneity at each locus and, globally, in the genetic profiles between the 7 Balearic cat populations taken into account; b) find out if this heterogeneity found individually at each locus and globally is in any way spatially organized in Minorca and in the whole of Balearic islands; and c) investigate the possible origins of the 7 Balearic cat populations. RuizGarcia $(1988,1990$ b) stated that there were 2 areas on the Spanish Mediterranean coast with differentiated genetic pools in their cat populations. One of these is Catalonia, where we found genetic profiles similar to Greek and North-African cat populations, and the other is Spanish Levante, where the western European influence is substantially clearer. It would be interesting to find out to which of the 2 areas the Balearic cat populations belong. Previously, Dyte (unpublished data) and Robinson (unpublished data) (both of these references can be found in Lloyd and Todd, 1989) obtained small samples of cats in unspecified areas of the Balearic Islands. These were probably not representative of all of the islands and could not answer the questions that we will study here (for example, Robinson's sample in Majorca consisted of 45 cats).

\section{MATERIAL AND METHODS}

\section{Populations and alleles studied}

A total number of 2096 cats was observed in Minorca, Majorca and Ibiza (Balearic islands) between March 1989 and March 1990. In Minorca, 1348 cats were seen (Mahon, $n=474$ cats; Villacarlos, $n=226$ cats; Mercadal and Alayor, $n=104$ cats Ciudadela, $n=510$ cats; the remaining 34 cats were seen in other parts of Minorca: principally Fornells, Cala en 'Porter, Punta Prima and Binibeca). In Majorca (Palma Majorca and nearby populations), 475 cats were observed. In Ibiza, 273 cats were sampled (Ibiza, city, $n=210$ and San Antonio, $n=63$ ). Each of these populations was extensively sampled to minimise whatever effects there might be of local deviations in allele frequencies. Each cat sampled was a stray, an alley-cat, a feral cat or "pseudo-wild". Careful measures were taken in order not to repeat the observation of a cat previously examined in the different incursions made into these Balearic localities (fig 1).

The phenotypes of the cats were recorded directly from observation of the animals and the genetic nomenclature used is in accordance with the Committee on Standardized Genetic Nomenclature for Cats (1968). The genetic characteristics studied here included (table I): sex-linked $(O, o$; Orange vs non-orange); the autosomial loci, $A\left(A, a\right.$; Agouti vs Non-agouti); $T\left(t^{b}, t^{+}, T^{a}\right.$; Blotched $v s$ Mackerel vs Abyssinian tabby); $D$ ( $D, d$; Intense colour vs Dilute colour); $L$ ( $L, l$; Short hair vs Long hair); $S(S, s$; White spotting vs Non-white spotting); $W(W, w$; Dominant white vs Normal colour); $C\left(C, c^{s}\right.$; Full colour vs Siamese); $M(M, m$; Manx vs Normal tail). The inheritance and interactions of these factors have been previously discussed in detail by Robinson (1977) and Wright and Walters (1982). Since the sex of all the animals could not be determined, a maximum likelihood 


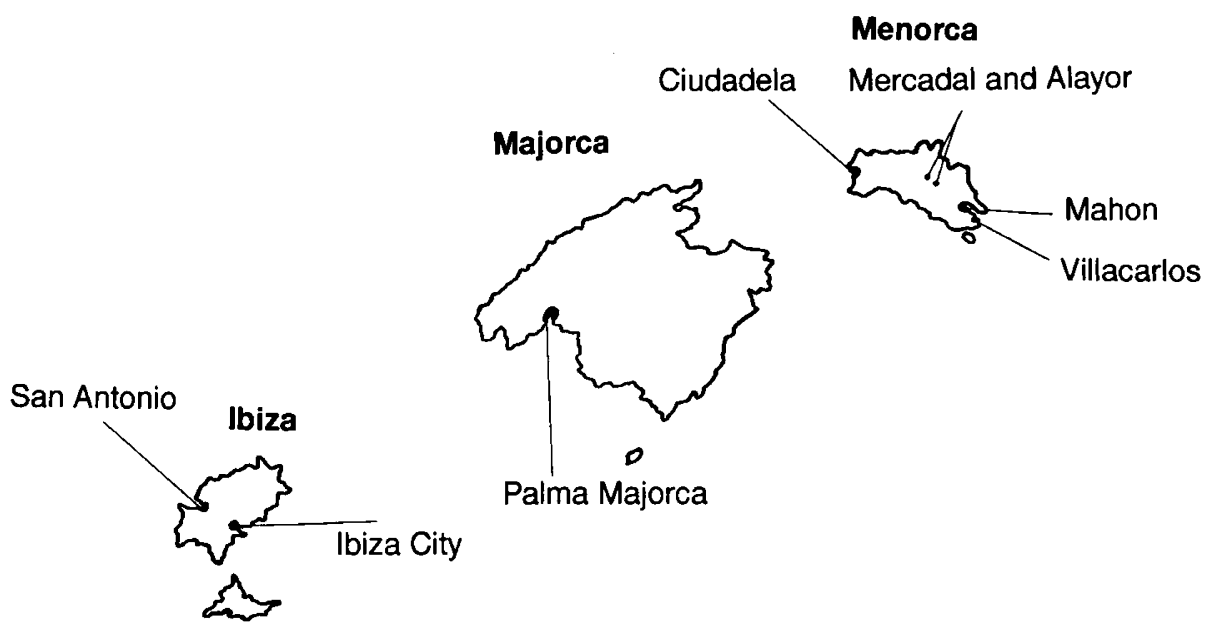

Balearic Islands

Fig 1. Map of the Balearic islands with the 7 Balearic cat populations studied (Scale: 1: 2000000 ).

approximation, assuming a 1:1 sex ratio (a fraction of the sample was sexed and did not significantly differ from a 1:1 sex ratio), was used to estimate the frequency of Orange (Robinson, 1972), $p(O)=(2 a+b) / 2 N$, where $a=$ number of Orange $(O / O$ and $O /-)$ phenotypes, $b=$ number of tortoiseshell $(O /+)$ phenotypes, $N=$ total sample size and $p$ is the frequency of Orange. The standard error for the estimate of Orange was obtained by the formula used by Robinson and Machenko (1981):

$$
\sqrt{p(2-3 p) /(3-4 p) N}
$$

A test for random mating at the $O$ locus was performed using a $G$ test (Sokal and Rohlf, 1981) that compared observed phenotypes to those predicted from the estimated mutant allele frequency.

Recessive mutant frequencies $(q)$ are taken as the square roots of observed phenotypic frequencies, while dominant mutant frequencies $(p)$ are taken as $1-q$. Standard errors are given by the formulae:

$$
\sqrt{1-q / 4 N} \text { and } \sqrt{(2-p) / 4 N}
$$

for recessive and dominant alleles, respectively.

Sample sizes for the various loci are different because Orange is epistatic to Agouti, Non-agouti is epistatic to Tabby and Dominant white is epistatic to all other coat colours. Futher, some diagnoses are difficult or impossible due to high grades of White spotting and/or unfavourable viewing conditions. 
Table I. Description of the 9 genes studied in 7 Balearic cat populations.

\begin{tabular}{lcl}
\hline Locus & Allele & Characteristic \\
\hline$O$ (sex-linked gene) & $o$ & Wild; pigmentation no orange \\
& $O$ & Mutant; all pigment is orange; epistatic to the \\
& & observation of the $A$ locus \\
(autosomal gene) & $A$ & Wild; colour Agouti \\
& $a$ & Mutant; colour Non-agouti; self-colour; black colour; \\
& & recessive; epistatic to the observation \\
& of the $T$ locus
\end{tabular}

Different studies seem to confirm that all these autosomal loci are mutually unlinked.

\section{Genetic heterogeneity and theoretical gene flow}

To estimate the genetic heterogeneity due to these genes between the Minorcan cat populations and between all the Balearic cat populations studied, the Wright's $F_{s t}$ statistic (Wright, 1969, 1978) was used. In this work, the $F_{s t}$ estimates were corrected for sampling error using the expression $q(1-q) / 2 N$ ( $q$ is the allele frequency studied and $N$ is the number of individuals) (Nei and Imazumi, 1966; Wright, 1978). Seven loci $(O, A, T, D, L, S, W)$ were used to compute the $F_{s t}$ statistics. To test for genetic heterogeneity, the chi-square statistic for an $M \chi N$ contingency table with $(M-1)(N-1)$ degrees of freedom where $M$ is the number of populations and $N$ the number of alleles, was used as introduced by Workman and Niswander (1970). Indirect $(\mathrm{Nm})$ gene-flow estimates were obtained from these $F_{s t}$ values. This can be estimated assuming an $n$-dimensional island model (Takahata, 1983; Crow and Aoki, 1984) by the expression: $N m=\left[\left(1 / F_{s t}\right)-1\right] /\left\{4[n /(n-1)]^{2}\right\}$, where $n$ is the number of populations taken into account. 
In this model, it is assumed that the effects of migration and genetic drift are balanced in a subdivided population. These gene-flow values are probably underestimate of the real gene-flow values, overall, if there is a strong geometric component between the populations (Kimura and Weiss, 1964) (eg, Slatkin (1985) stated that the infinite island model underestimates $N m$ for a 1-dimensional stepping-stone model).

The phenotypic frequencies at each locus of each cat population were also compared to other cat populations using a $2 \times 2$ chi-square contingency test (Simpson et al, 1960) with Yates' correction for continuity.

\section{Spatial autocorrelation analysis}

To study whether the genetic heterogeneity between the Balearic cat population has a significant spatial trend, a spatial autocorrelation analysis was employed (Sokal and Oden, 1978ab; Sokal and Wartemberg, 1983). Spatial autocorrelation is the dependence of the value of a particular variable at 1 location on the value of that same variable at other nearby locations or at determined geographic distance. The spatial autocorrelation statistic employed was Moran's I index (Sokal and Oden, 1978a). To carry out this spatial analysis, 4 distance classes were defined $(1 \mathrm{DC}=$ $0-29 \mathrm{~km} ; 2 \mathrm{DC}=29-162 \mathrm{~km} ; 3 \mathrm{DC}=162-303 \mathrm{~km} ; 4 \mathrm{DC}=303-339 \mathrm{~km})$ where each particular distance class was chosen to optimize the allocation of locality pairs (an equal number of point pairs) among distance classes. A binary connection matrix was formed according to Sokal and Oden (1978b) and to determine statistical significance for autocorrelation coefficients, the Bonferroni procedure was used (Oden, 1984).

\section{Genetic distances}

Three measures of genetic relationships were employed. The Nei genetic distance (Nei, 1972) was one of these. The values DNei $<20.00$ (multiplied by 1000 ) will be taken to indicate a close genetic relationship between the different cat populations analyzed (Ahmad et al, 1980; Ruiz-Garcia, 1990c). Values $20.00<\mathrm{DNei}<40.00$ will be taken as intermediates in the genetic relationships between populations (Klein et al, 1988). The Nei genetic distance is a good index when it measures the genetic divergence in accordance with the neutralist evolution theory (Kimura, 1983). Nevertheless, some polymorphic loci in the cat populations could be under the action of diversifying natural selection (Blumenberg, 1977; Blumenberg and Lloyd, 1980; Lloyd, 1985). For this reason, we have also used the Prevosti genetic distance (Prevosti, 1974; Prevosti et al, 1975). This genetic index is independent of selective or neutral processes and recurrent or non-recurrent processes. In addition, the Cavalli-Sforza and Edwards (1967) chord distance was used, as it has mathematical properties different from the 2 genetic distances mentioned above. Additionally Nei et al (1983) showed that assuming a constant evolution rate, the dendrograms produced when using the UPGMA algorithm and the Wagner method with the Cavalli-Sforza and Edwards (1967) distance are those which produce the most precise topology of the branches.

In this study, 7 loci $(O, A, T, D, L, S, W)$ were taken into account to obtain the genetic relationships within the Balearic cat populations and between these cat 
populations and 70 selected European and North-African cat populations. The genetic profiles of all of these cat populations can be found in Ruiz-Garcia (1988, 1990abc) and Lloyd and Todd (1989). Manx $(M)$ and Siamese $\left(c^{s}\right)$ are not included in this analysis because they are rarely found above trace levels or are exotic characters.

In order to compare the genetic relationships of a fixed pair of Balearic populations to the relationships between another pair of Balearic populations (using the 7 mentioned loci), we have used Nei's (1978) genetic identity $I$ coefficient with variance $S D I^{2}=[(1-I) / I n]^{2}$ where $n$ is the number of loci analyzed.

\section{Mantel's test}

The Mantel's test (Mantel, 1967; Hubert et al, 1981; Hubert and Golledge, 1982) has been used to detect for possible relationships between the genetic distance matrices obtained between the Minorcan cat populations and Balearic cat populations and the geographic distance matrices. In this work, Mantel's statistic was normalized using the Smouse et al (1986) technique, which converts Mantel's statistic into a correlation coefficient. In order to observe whether the type of data may have some repercussion on the correlations, linear, logarithmic, exponential and power functions were used. Using a Monte-Carlo simulation (2 000 permutations) or using an approximate Mantel $t$-test, we can test the significance of the correlations obtained.

\section{Statistical studies of the 4 main Balearic populations and the large geographical clusters}

The 4 main Balearic populations studied here (Mahon, Ciudadela, Palma Majorca and Ibiza) were related to the 70 European and North-African populations selected using geographical clusters for each country to which these populations belong. To find out whether there are significant differences between average Nei genetic distances between the different geographical clusters for the same Balearic population or to see whether there are significant differences between the different Balearic populations in relation to a fixed geographical cluster, we used different statistical techniques. When the possible existence of significant statistical differences between the average values of the Nei distance of the different geographical clusters to a fixed Balearic population was suspected, an analysis of the variances of the Nei average distances was carried out. All the $F$-tests for the comparison between eastern Mediterranean and North-African (Greek and North-African) clusters and western European clusters (France and Great Britain) proved to be significant. Because of this, these comparisons of means were carried out with a non-parametric test (Mann-Whitney $U$-test; Hollander and Wolfe, 1973). For the second case, in which the possible significant differences between the Nei average distance between the different Balearic populations to the same geographical cluster were studied, we were able to observe the existence of normality on most occasions by means of the Kolmogorov-Smirnov test using Lilliefors' tables (Lilliefors, 1967). We did not observe any significant differences between the variances on most occasions, so we used Student' $t$-test for small samples (Sarria et al, 1987). 


\section{Phenograms and cladograms}

Different kinds of dendrograms were constructed to explain the genetic relationships between the cat populations of Minorca, between the cat populations in the Balearic islands and between these populations and other European and NorthAfrican populations. To do this, we carried out a phenetic approach using different algorithms. These algorithms used were the UPGMA procedure (unweighted pairgroup method), the SINGLE procedure (single-linkage clustering). The description of these algorithms can be found in Sneath and Sokal (1973) and Dunn and Everitt (1982). To the different dendrograms which were obtained, goodness-of-fit statistics were applied to find the differences between the original genetic distance matrices (input) and the patristic distances (output). These goodness-of-fit statistics are as follows: Farris's F (1972), Prager and Wilson's F (1976), Fitch and Margoliash's standard deviation (1967) and the cophenetic correlation coefficient (Sneath and Sokal, 1973). In addition, some strict consensus trees (Rohlf, 1982) were constructed between the dendrograms by means of different algorithms and different genetic distances, but they are not shown in this article. To the populations in Minorca and the whole of the Balearic populations, a cladogenetic analysis by means of Wagner's method (Farris, 1972) was applied to find out whether the results obtained through this method are highly similar to those obtained through a phenetic analysis. This analysis was carried out using the Sforza and Edwards (1967) distance. For the development of this method we used the OTUS addition sequence by means of the multiple addition criterion (MAC) algorithm (Swofford, 1981) and the tree was rotated in order to produce a tree conducted by the midpoint rooting method (Farris, 1972). Some cladograms were also constructed for the Balearic populations in which the Mahon population was regarded as the root of the tree in relation to the rest of the populations (outgroup method). This will help us to ascertain how the other populations have differed from the population of Mahon (one of the assumed points of introduction of cats into Minorca).

\section{Percentage of genetic heterogeneity attributed to each locus and to each population with the method of Adalsteinsson et al (1979)}

In order to calculate the genetic heterogeneity percentage which each locus contributes to the total genetic heterogeneity of the loci studied, and calculate the genetic heterogeneity that can be attributed to each population, pairs of genetic differences between populations using Kidd and Cavalli-Sforza's (1974) genetic distance have been used in the same way as was done by Adalsteinsson et al (1979), where :

$$
D=\sum_{n}\left(1-\sum \sqrt{P_{i k} \cdot P_{j k}}\right)
$$

where $p_{i k}$ is the frequency of the $k$ allele in the $j$ sample, $p_{j k}$ is the frequency of the $k$ allele in the $j$ sample and $n$ is the number of the loci taken into account. This analysis was applied to the Balearic populations and to some Iberian populations. This analysis allows us to find out which loci introduce heterogeneity and which populations contribute to the genetic heterogeneity. 


\section{RESULTS}

\section{Phenotypic frequencies, gene frequencies and Hardy-Weinberg equi- librium}

In table II, we give the gene frequencies for the 7 cat populations studied in the Balearic islands. In table III, the results of the application of a $G$ test to the $O$ locus are shown in order to check Hardy-Weinberg equilibrium in these populations. There was no significant statistical deviation between the observed proportions and those expected for the populations of Ibiza city, San Antonio (Ibiza), Palma Majorca (Majorca), Mahon and Villacarlos (Minorca). So we can conclude that in these populations there are no evolutionary agents able to deviate the proportions of homozygotes and heterozygotes from Hardy-Weinberg equilibrium. However, it turned out that the Hardy-Weinberg equilibrium did not apply at the $O$ locus for the Minorca sample as a whole, and for the samples from Ciudadela and Mercadal and Alayor (Minorca) which have an excess of homozygotes. In spite of this, the factor (or factors) that increases the proportion of homozygotes significantly does not affect allele frequencies (Scribner et al, 1991).

\section{Genetic differentiation and theoretical gene flow}

The global genetic differentiation between the cat populations of Minorca $\left(F_{s t}=\right.$ $0.0151)$ and between all of the Balearic populations studied here $\left(F_{s t}=0.0299\right)$ are small (table IV). This means that any population has an average value of $98.49 \%$ and $97.01 \%$ of the total genetic diversity found in the total population of Minorca and the Balearic population as a whole, respectively. The values of theoretical gene flow in an $n$-dimensional island model for the cat populations of Minorca were 9.16 cats entering per generation and population as an on average value and 5.94 for the islands as a whole. These values are much higher than those found for other organisms studied. Nevertheless, the existence of statistically significant heterogeneity can be observed. In Minorca and in the Balearics as a whole, all the alleles (except the $W$ allele) showed the existence of significant heterogeneity. Another aspect that can be observed is that the relative quantity of genetic heterogeneity introduced by each locus is highly different. For Minorca, the $t^{b}$ allele $\left(F_{s t}=0.0567\right)$ is the one which introduces the most genetic heterogeneity and the $W\left(F_{s t}=0.0000\right)$ and $O\left(F_{s t}=0.0042\right)$ alleles are those which introduce the least heterogeneity. When we consider the Balearic populations as a whole, the $t^{b}\left(F_{s t}=0.0693\right)$ and $l\left(F_{s t}=0.0526\right)$ alleles are those which introduce the most genetic heterogeneity, while $W\left(F_{s t}=0.0008\right)$ and $O\left(F_{s t}=0.0065\right)$ are the alleles which introduce the least heterogeneity.

When we considered each allele individually between pairs of populations (table V) we also observed a great number of significantly differentiating alleles. For example, out of 9 alleles studied, the population of Mahon differs in 5 alleles from the population of Palma Majorca and in 7 alleles from the population of Ibiza, or, for example, the population of Villacarlos differs significantly in 4 alleles from the populations of Palma Majorca and Ibiza. 


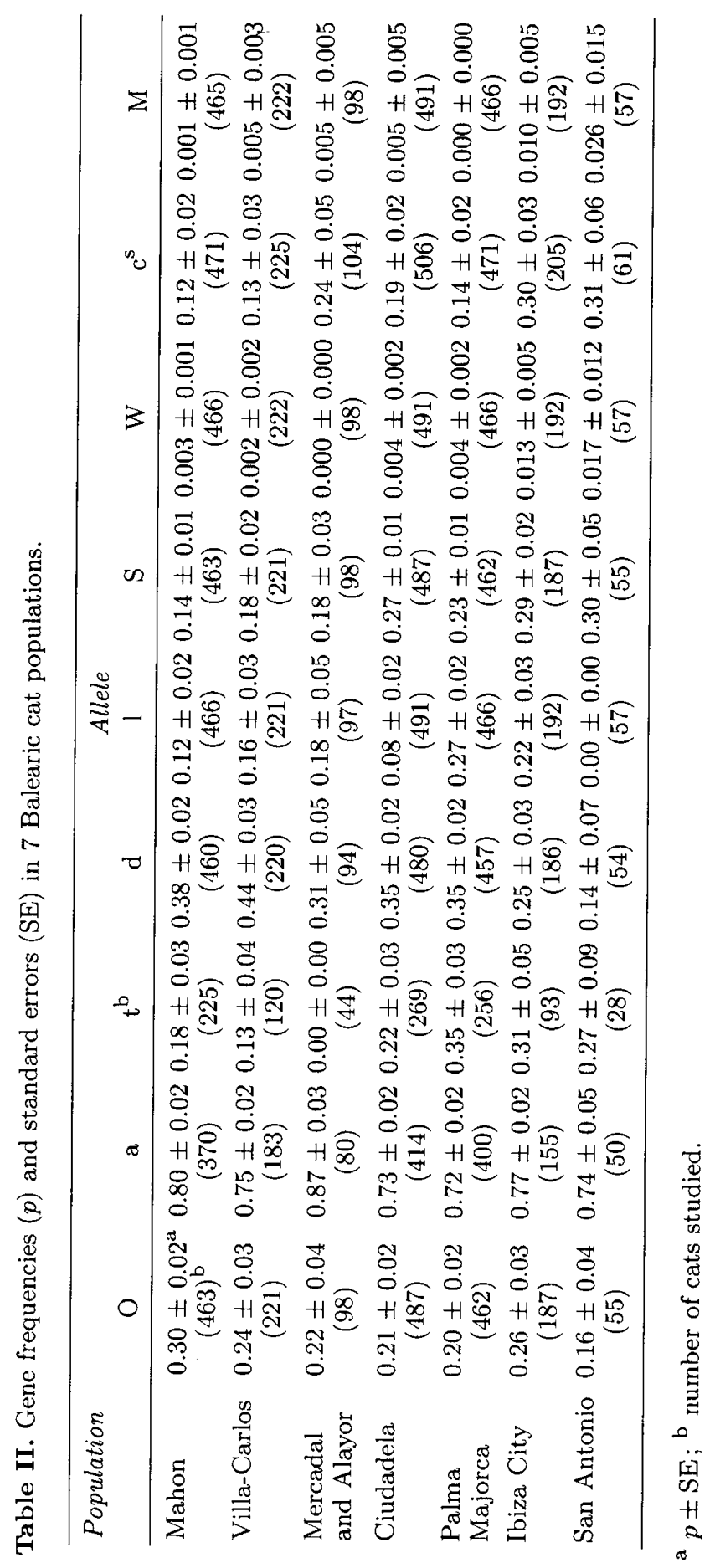




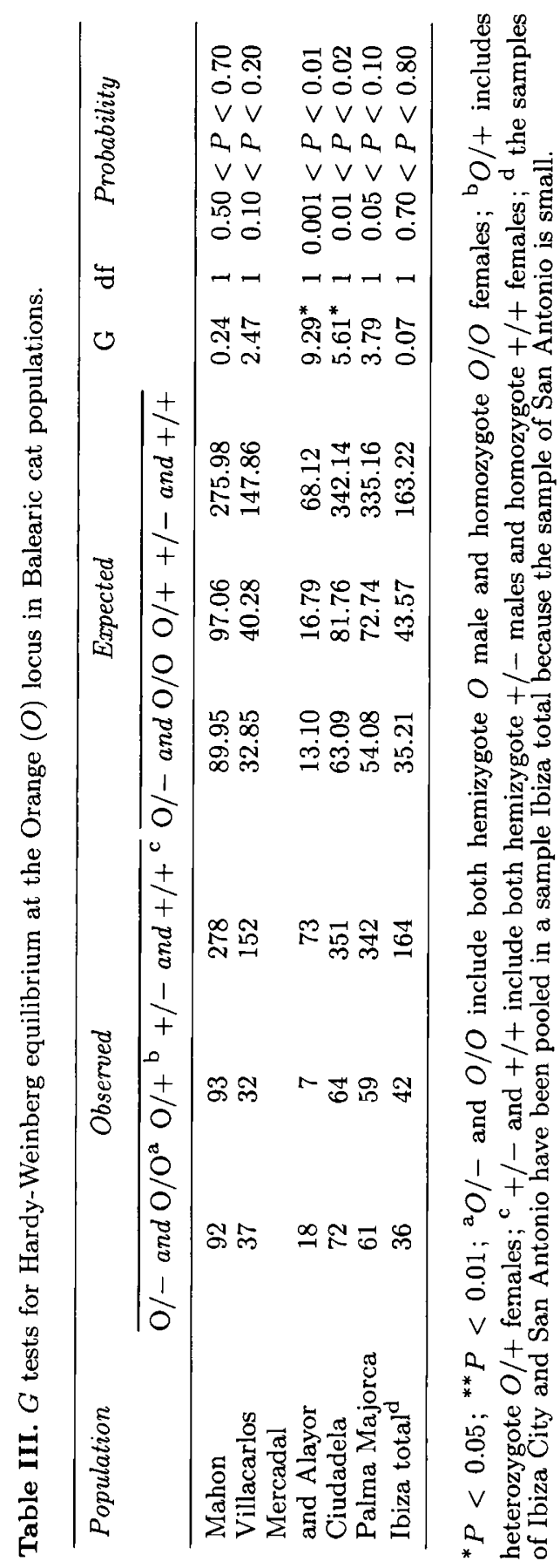


Table IV. Gene diversity using the $F_{s t}$ index (calculated by the method of Nei, 1977) and the $\chi^{2}$ test (calculated by the method of Workman and Niswander, 1970) and theoretical gene flow estimates using the Takahata (1983) method.

\begin{tabular}{|c|c|c|c|c|c|}
\hline \multicolumn{6}{|c|}{ Minorca } \\
\hline Allele & $\mathrm{F}_{s t}$ & $\mathrm{Nm}$ & $\chi^{2}$ & $\mathrm{df}$ & Probability \\
\hline$O$ & 0.0042 & 33.45 & 20.98 & 3 & $P<0.001$ \\
\hline$a$ & 0.0174 & 7.92 & 24.53 & 3 & $P<0.001$ \\
\hline$t^{b}$ & 0.0567 & 2.33 & 29.69 & 3 & $P<0.001$ \\
\hline$d$ & 0.0070 & 19.80 & 13.64 & 3 & $P<0.001$ \\
\hline$l$ & 0.0099 & 14.04 & 30.74 & 3 & $P<0.001$ \\
\hline$S$ & 0.0111 & 12.46 & 47.52 & 3 & $P<0.001$ \\
\hline$W$ & 0.0000 & - & 1.01 & 3 & 0.79963 \\
\hline Average & 0.0151 & 9.16 & 168.11 & 21 & $P<0.001$ \\
\hline \multicolumn{6}{|c|}{ Balearic islands } \\
\hline Allele & $\mathrm{F}_{s t}$ & $\mathrm{Nm}$ & $\chi^{2}$ & $\mathrm{df}$ & Probability \\
\hline$O$ & 0.0065 & 27.83 & 36.87 & 6 & $P<0.001$ \\
\hline$a$ & 0.0114 & 15.85 & 34.48 & 6 & $P<0.001$ \\
\hline$t^{b}$ & 0.0693 & 2.46 & 98.59 & 6 & $P<0.001$ \\
\hline$d$ & 0.0344 & 5.15 & 56.05 & 6 & $P<0.001$ \\
\hline$l$ & 0.0526 & 3.30 & 174.946 & 6 & $P<0.001$ \\
\hline$S$ & 0.0146 & 12.40 & 64.33 & 6 & $P<0.001$ \\
\hline$W$ & 0.0008 & 231.43 & 11.58 & 6 & 0.07210 \\
\hline Average & 0.0299 & 5.94 & 476.84 & 42 & $P<0.001$ \\
\hline
\end{tabular}

Table V. Summary of loci that significantly differ between Balearic cat populations using chi-square comparisons with Yates' correction for continuity $(P<0.05)$.

\begin{tabular}{|c|c|c|c|c|c|c|}
\hline & 1 & 2 & 3 & 4 & 5 & 6 \\
\hline 1 & - & $O, a$ & $O, c^{s}$ & $O, a, S$ & $O, a, t^{b}, l, S$ & $O, t^{b}, d, S, W, M, c^{s}$ \\
\hline 2 & & - & $a, d$ & $d, l, S$ & $t^{b}, d, l, S$ & $t^{b}, d, S, c^{s}$ \\
\hline 3 & & & - & $a$ & $a, c^{s}$ & $a, S$ \\
\hline 4 & & & & - & $t^{b}, l$ & $d, l, c^{s}$ \\
\hline 5 & & & & & - & $d, l, S, c^{s}$ \\
\hline 6 & & & & & & - \\
\hline
\end{tabular}

$1=$ Mahon; $2=$ Villacarlos; $3=$ Mercadal and Alayor $4=$ Ciudadela $; 5=$ Palma Majorca; 6 = Ibiza total. (The samples of Ibiza City and San Antonio have been pooled because the San Antonio sample is small and there are no significant differences between the 2 samples.) 


\section{Spatial autocorrelation}

The $O, a, l$ alleles do not show any kind of significant spatial structure. The $t^{b}$ allele, on the other hand, has 3 statistically significant Moran's $I$ coefficients, though it does not reach a significant global correlogram (table VI). Between $0-29.2 \mathrm{~km}$ and $29.2-162.1 \mathrm{~km}$, the values are significantly positive (high similarity for the $t^{b}$ allele frequencies). On the contrary, between 302.8 and $338.8 \mathrm{~km}$, the value is significantly negative (highly different $t^{b}$ allele frequencies). The $d, S$, and $W$ alleles have significant spatial patterns $(P=0.022, P=0.001, P=0.001$, respectively). In the 3 cases there are significantly positive Moran's $I$ values for the first distance class and Moran's $I$ values are significantly negative for the fourth distance class $(302.8-338.8 \mathrm{~km}$ ) (genetic differentiation at long distance). The $d$ and $W$ alleles showed a stronger monotonic clinal tendency than the $S$ allele which rather showed genetic differentiation at long distance. The average correlogram shows a clear clinal monotonic tendency for the 7 alleles studied as a whole with a progressive diminution of genetic similarity as geographical distances increases.

Table VI. Spatial autocorrelation with Moran's $I$ index of 7 alleles $\left(O, a, t^{b}, d, l, S, W\right)$ and average coefficients. Distances classes are identified by their upper limit the 4 distance classes have equal number of points in each classes.

\begin{tabular}{|c|c|c|c|c|c|}
\hline \multirow[t]{2}{*}{ Allele } & \multicolumn{4}{|c|}{$\begin{array}{c}\text { Moran's I index } \\
\text { distance class }(\mathrm{km})\end{array}$} & \multirow[t]{2}{*}{ Cgram prob } \\
\hline & 29 & 162 & 303 & 339 & \\
\hline$O$ & -0.175 & 0.035 & -0.234 & -0.272 & 1.000 \\
\hline$a$ & -0.274 & 0.224 & -0.361 & -0.241 & 0.429 \\
\hline$t^{b}$ & $0.476^{*}$ & $0.390^{*}$ & -0.727 & $-0.700^{*}$ & 0.125 \\
\hline$d$ & $0.423^{*}$ & -0.031 & -0.043 & $-0.874^{*}$ & 0.022 \\
\hline$l$ & -0.373 & -0.512 & 0.237 & -0.043 & 0.540 \\
\hline$S$ & $0.796^{*}$ & -0.326 & 0.338 & $-1.256^{*}$ & 0.001 \\
\hline$W$ & $0.852^{*}$ & -0.104 & -0.054 & $-1.162^{*}$ & 0.000 \\
\hline Average & 0.25 & -0.05 & -0.12 & -0.65 & \\
\hline
\end{tabular}

${ }^{*} P<0.05 ;{ }^{a}$ Cgram prob: probability of global correlogram.

\section{Mantel's test}

Mantel's tests to prove associations between geographical and the Nei and Prevosti genetic distances for the cat populations of Minorca and for the Balearic cat populations as a whole were analyzed. For the Nei distance in Minorca, geographical separation explains between $2.25 \%$ (linear regression; $r=0.15023, t=0.315$, $P=0.3762$; Monte-Carlo simulation (2000 permutations at random) $P=0.484$ ) and $42.68 \%$ (logarithmic transformation; $r=0.65332, t=1.452, P=0.0732$; Monte-Carlo: $P=0.1785)$ for genetic variability. For the Prevosti distance, geographical distance explains between $4.70 \%$ (linear regression; $r=0.21673$, 
$t=0.454, P=0.3249$; Monte-Carlo: $P=0.497$ ) and $36.87 \%$ (logarithmic transformation; $r=0.60721, t=1.350, P=0.0855$; Monte-Carlo: $P=0.1620$ ) of genetic variability. In no case were these values significant. Thus we can state that geographical distances between populations of Minorca do not have an observable significant effect on the constitution of the genetic profiles of the cat populations on this island. However, when we consider all the Balearic cat populations studied (in this case those of San Antonio and Ibiza City were considered as one sample) geographical distance explains between $31.57 \%$ (power transformation; $r=0.56187$, $t=1.959, P=0.0251$; Monte-Carlo: $P=0.0067$ ) and $46.20 \%$ (logarithmic transformation; $r=0.67975, t=2.414, P=0.0079$; Monte-Carlo: $P=0.0123$ ) of the genetic heterogeneity (in both cases, these values were significant). Unlike what was observed in Minorca, for the Balearic populations as a whole, geographical distance significantly explains between a third and a half of the total genetic heterogeneity found for these populations.

\section{Genetic identities between the Balearic populations studied}

A question which has been studied here is which of the 2 most important populations in Minorca (Mahon and Ciudadela, the 2 harbours) has most decisively influenced the other 2 small populations that have been studied on this island (Villacarlos and Mercadal and Alayor) (table VII). We can prove that the population of Mahon is significantly more similar to the populations of Villacarlos and Mercadal and Alayor than the population of Ciudadela $(t=11.64,12 d f, P<$ $0.001 ; t=7.524,12 d f, P<0.001)$. We also observe that the population of Mahon is significantly more similar to the 2 mentioned populations on the same island than the rest of Balearic cat populations studied (for Villacarlos: Mahon-Palma: $t=15.50,12 d f, P<0.001$; Mahon-Ibiza: $t=15.68,12 d f$, $P<0.001$; Mahon-San Antonio: $t=16.69,12 d f, P<0.001$; For Mercadal and Alayor: Mahon-Palma: $t=12.573,12 d f, P<0.001$; Mahon-Ibiza: $t=10.52$, $12 d f, P<0.001$; Mahon-San Antonio: $t=12.57,12 d f, P<0.001)$. We also wanted to find out which of the 2 most important populations in Minorca is most similar to the rest of Balearic populations. Ciudadela turned out to be significantly more similar to the populations of Palma Majorca and those of Ibiza and San Antonio, than what was observed for the population of Mahon $(t=3.93,12 d f, P<0.05 ; t=6.51,12 d f, P<0.001 ; t=11.17,12 d f$, $P<0.001$, respectively). This shows that the populations in central-eastern Minorca (Mahon, Villacarlos, Mercadal, Alayor) differ slightly but significantly from the rest of Balearic populations studied here.

\section{Differences between the large geographical clusters and the 4 most important Balearic populations studied}

When we compare the Nei average genetic distances between 2 large geographical groups (Greece and North Africa $(n=14)$ and Great Britain and France $(n=25))$ and the 4 most important Balearic populations (tables VIII and IX), we observe significantly lower mean values for the group containing Greece and North Africa than for Great Britain and France (the range for Greece and North Africa is 
Table VII. Nei (1978) unbiased genetic identity $(I)$ between the Balearic cat populations studied.

\begin{tabular}{|c|c|c|c|c|c|c|c|}
\hline Populations & 1 & 2 & 3 & 4 & 5 & 6 & 7 \\
\hline 1 & - & $\begin{array}{l}\quad 0.998 \\
\pm 0.00028\end{array}$ & $\begin{aligned} & 0.992 \\
\pm & 0.00115\end{aligned}$ & 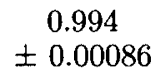 & 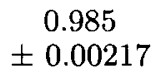 & 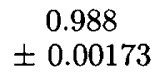 & $\begin{aligned} & 0.977 \\
\pm & 0.00336\end{aligned}$ \\
\hline 2 & & - & 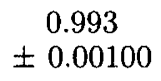 & $\begin{aligned} & 0.994 \\
\pm & 0.00086\end{aligned}$ & $\begin{array}{ll} & 0.986 \\
\pm & 0.00203\end{array}$ & $\begin{aligned} & 0.985 \\
\pm & 0.00217\end{aligned}$ & $\begin{aligned} & 0.972 \\
\pm & 0.00411\end{aligned}$ \\
\hline 3 & & & - & 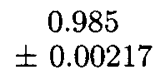 & $\begin{aligned} & 0.971 \\
\pm & 0.0042\end{aligned}$ & 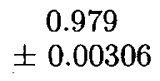 & $\begin{array}{c}0.971 \\
\pm 0.00427\end{array}$ \\
\hline 4 & & & & - & $\begin{array}{ll} & 0.989 \\
+ & 0.00158\end{array}$ & $\begin{array}{ll} & 0.993 \\
\pm & 0.00100\end{array}$ & $\begin{aligned} & 0.992 \\
\pm & 0.00115\end{aligned}$ \\
\hline 5 & & & & & - & $\begin{array}{ll} & 0.996 \\
\pm & 0.00057\end{array}$ & $\begin{aligned} & 0.977 \\
\pm & 0.00336\end{aligned}$ \\
\hline 6 & & & & & & - & $\begin{array}{ll} & 0.990 \\
\pm & 0.00144\end{array}$ \\
\hline 7 & & & & & & & - \\
\hline
\end{tabular}

$1=$ Mahon $; 2=$ Villacarlos $; 3=$ Mercadal and Alayor $; 4=$ Ciudadela $; 5=$ Palma Majorca; $6=$ Ibiza City; $7=$ San Antonio; standard errors were calculated by the expression: $\mathrm{SD}=(1-I) /(I n)$ where $n$ is the number of loci studied.

12.12 $\pm 5.79-29.35 \pm 9.34$ while that for Great Britain and France is $46.39 \pm 18.44-$ $106.51 \pm 26.89$ ). We also observe that the populations of Ciudadela and Ibiza show significantly lower mean values of the Nei distance with the group of Greece and North Africa than those of Palma Majorca and Mahon (Ibiza vs Palma: $t=5.11$, $P<0.001$; Ibiza vs Mahon: $t=3.83, P<0.001$; Ciudadela vs Mahon: $t=10.51$, $P<0.001$ and Ciudadela vs Palma: $t=4.54, P<0.001)$. These comparisons show that all the Balearic cat populations are genetically more similar to the east Mediterranean and North-African cat populations than to the western European ones with regard to the coat genes. We also observe that the population of Palma Majorca is the one that presents the least difference between both groups of clusters, being the Balearic population which seems the most closely related to the genetic profiles of some western European cat populations (especially some French and Italian populations). With, for example, the Prevosti average distance, the value of Palma Majorca for the eastern Mediterranean and North-African group $(n=25)(\widetilde{D}=10.01 \pm 2.29)$ is practically identical to the western European group $(n=33)(\widetilde{D}=10.99 \pm 2.44)$.

\section{Phenetic and cladogenic study}

All the phenetic and cladogenetic analyses of the 4 populations of Minorca offer the same groupings between the populations regardless of the algorithms and genetic distances used (fig 2). Mercadal and Alayor is the population which most clearly differs from the rest of the populations on this island. The best goodness-of-fit 
Table VIII. Mean values of the Nei genetic distance $(\times 1000)$ and Prevosti genetic distance $(\times 100)$ for Mahon, Ciudadela, Palma Majorca, Ibiza City versus European and North-African clusters. Nei genetic distance have been calculated with 7 loci $(O, A, T, D, L, S, W)$; the Prevosti genetic distance, shown in parentheses, have been calculated with 6 loci $(O, A, T, D, L, S)$.

\begin{tabular}{|c|c|c|c|c|}
\hline Group & Mahon & Ciudadela & Palma & Ibiza \\
\hline$n=5)$ & $\begin{array}{c}30.36 \pm 5.97 \\
(12.50 \pm 1.34)\end{array}$ & & $\begin{array}{l}22.10 \pm 4.23 \\
(8.99 \pm 0.89)\end{array}$ & $\begin{array}{l}11.80 \pm 3.49 \\
(6.83 \pm 0.94)\end{array}$ \\
\hline Port & & & & $\begin{array}{l}14.34 \\
(8.33\end{array}$ \\
\hline $\begin{array}{l}\text { Eastern } \\
\text { Mediterranean and } \\
\text { North Africa }(n=25)\end{array}$ & $\begin{array}{c}36.47 \pm 6.61 \\
(12.99 \pm 1.24)\end{array}$ & $\begin{array}{l}20.24 \pm 7.06 \\
(8.86 \pm 1.47)\end{array}$ & $(10.01 \pm 1$ & $\begin{array}{l}18.40 \pm 4.84 \\
(8.78 \pm 1.08)\end{array}$ \\
\hline North Africa $(n=7)$ & $\begin{array}{c}27.99 \pm 2.73 \\
(11.51 \pm 1.09)\end{array}$ & $\begin{array}{l}13.80 \pm 2.65 \\
(7.94 \pm 1.24)\end{array}$ & $\begin{array}{c}27.65 \pm 5.35 \\
(10.43 \pm 1.01)\end{array}$ & $\begin{array}{l}20.44 \pm 5.24 \\
(9.28 \pm 1.07)\end{array}$ \\
\hline Greece $(n=7)$ & $\begin{array}{c}30.71 \pm 6.22 \\
(12.31 \pm 1.33)\end{array}$ & $\begin{array}{l}10.44 \pm 3.07 \\
(6.84 \pm 1.23)\end{array}$ & $\begin{aligned} 20.84 & \pm 4 \\
(9.14 & \pm 1\end{aligned}$ & $\begin{array}{l}11.67 \pm \\
(7.38 \pm\end{array}$ \\
\hline Turkey $(n=6)$ & $\begin{array}{c}50.50 \pm 4.07 \\
(14.95 \pm 0.80)\end{array}$ & $\begin{array}{c}37.83 \pm 5.94 \\
(11.43 \pm 0.93)\end{array}$ & $\begin{array}{r}25.51 \pm 4 \\
(10.14 \pm 1\end{array}$ & $\begin{array}{l}24.20 \pm \\
(9.94 \pm\end{array}$ \\
\hline Israel $(n=$ & $\begin{array}{r}39.57 \pm 7 \\
(13.65 \pm 1\end{array}$ & $\begin{array}{l}21.89 \pm 7.28 \\
(9.89 \pm 1.54)\end{array}$ & $\begin{array}{c}23.53 \pm 6.54 \\
(10.50 \pm 1.37)\end{array}$ & $\begin{array}{l}17.98 \pm \\
(8.63 \pm\end{array}$ \\
\hline $\begin{array}{l}\text { Western Europe } \\
(n=33)\end{array}$ & $\begin{array}{r}95.68 \pm 15.47 \\
(18.12 \pm 1.34)\end{array}$ & $\begin{array}{c}74.48 \pm 15.64 \\
(14.52 \pm 1.63)\end{array}$ & $\begin{array}{c}43.15 \pm 9.25 \\
(10.98 \pm 1.22)\end{array}$ & $\begin{array}{c}51.72 \pm 10.42 \\
(12.29 \pm 1.14)\end{array}$ \\
\hline Italy $(n=3)$ & $\begin{array}{c}58.89 \pm 5.05 \\
(15.75 \pm 0.27)\end{array}$ & $\begin{array}{l}31.55 \pm 3.22 \\
(9.72 \pm 0.51)\end{array}$ & $\begin{array}{c}19.77 \pm 1.35 \\
(10.22 \pm 0.42)\end{array}$ & $\begin{array}{c}26.80 \pm 4.27 \\
(11.22 \pm 1.00)\end{array}$ \\
\hline Netherlands $(n=5)$ & $\begin{array}{c}63.36 \pm 7.25 \\
(15.75 \pm 0.27)\end{array}$ & $\begin{array}{c}42.34 \pm 5.03 \\
(11.06 \pm 0.57)\end{array}$ & $\begin{array}{c}26.94 \pm 3.46 \\
(10.17 \pm 0.40)\end{array}$ & $\begin{array}{l}26.41 \pm 4.32 \\
(8.90 \pm 0.58)\end{array}$ \\
\hline France $(n=12)$ & $\begin{array}{c}86.77 \pm 9.14 \\
(17.60 \pm 0.95)\end{array}$ & $\begin{array}{c}65.91 \pm 8.99 \\
(13.92 \pm 0.95)\end{array}$ & $\begin{array}{l}32.38 \pm 5.11 \\
(9.14 \pm 0.65)\end{array}$ & $\begin{array}{c}49.72 \pm 6.44 \\
(13.17 \pm 1.05)\end{array}$ \\
\hline $\begin{array}{l}\text { Great Britain } \\
(n=13)\end{array}$ & $\begin{array}{l}124.82 \pm 9.82 \\
(20.23 \pm 1.04)\end{array}$ & $\begin{array}{l}104.67 \pm 8.96 \\
(17.50 \pm 0.96)\end{array}$ & $\begin{array}{c}59.32 \pm 7.19 \\
(13.12 \pm 1.10)\end{array}$ & $\begin{array}{c}69.06 \pm 7.39 \\
(13.04 \pm 0.76)\end{array}$ \\
\hline
\end{tabular}

Table IX. Matrix of mean values $( \pm$ SD) of the Nei genetic distance $(\times 1000)$ for Mahon, Ciudadela, Palma, Ibiza City versus Greece and North Africa $(n=14)$ and Great Britain and France $(n=25)$ and $z$ tests for significant differences.

\begin{tabular}{lcccc}
\hline & $\begin{array}{c}\text { Greece } \\
\text { and North Africa }\end{array}$ & $\begin{array}{c}\text { Great Britain } \\
\text { and France }\end{array}$ & z test & Probability \\
\hline Mahon & $29.35 \pm 9.34$ & $106.51 \pm 26.89$ & $z=5.12$ & $P<0.01$ \\
Ciudadela & $12.12 \pm 5.79$ & $86.07 \pm 26.45$ & $z=5.12$ & $P<0.01$ \\
Palma Majorca & $24.25 \pm 10.15$ & $46.39 \pm 18.44$ & $z=3.69$ & $P<0.01$ \\
Ibiza & $16.06 \pm 8.67$ & $58.23 \pm 18.26$ & $z=4.90$ & $P<0.01$ \\
\hline
\end{tabular}


statistics for the phenograms and cladograms corresponds to the Cavalli-Sforza and Edwards distance (eg, the cophenetic correlation coefficient for the Cavalli-Sforza and Edwards distance is 0.966 , while for the Nei distance it is 0.796).
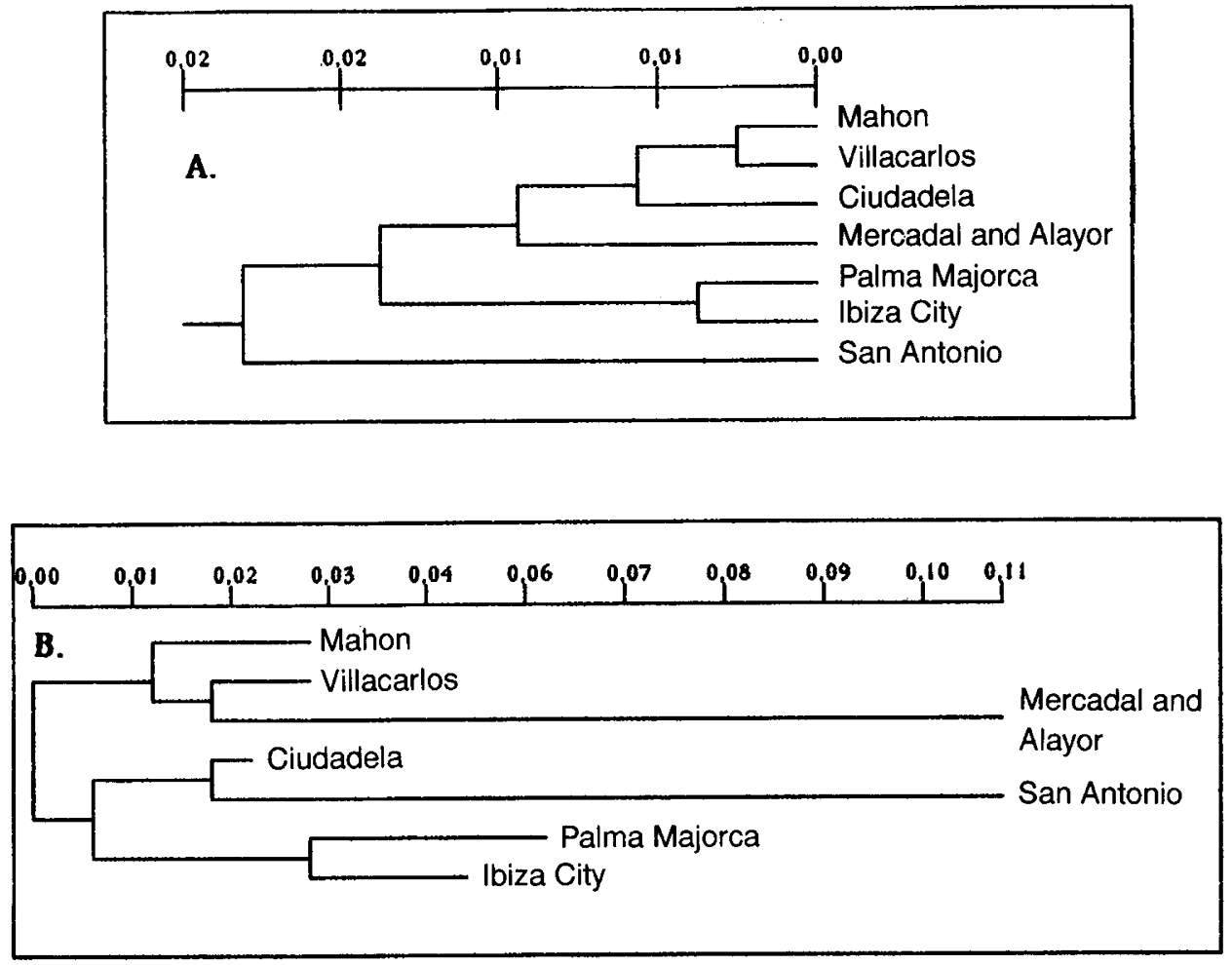

Fig 2. Phenetic and cladogenetic analyses of Balearic cat populations: (A) UPGMA phenetic analysis with the Nei (1972) distance. Goodness-of-fit statistics: Farris (1972) $F=0.092$; Prager Wilson (1976) $F=28.502$; Percentage of standard deviation of Fitch and Margoliash $(1967)=44.199$; Cophenetic correlation $N=0.711$. (B) Wagner cladogram with Cavalli-Sforza and Edwards (1967) distance using multiple addition criterion procedure. The tree is rooted using the midpoint rooting method. Goodnessof-fit statistics: Farris (1972) $F=0.136$; Prager and Wilson (1976) $F=6.386$; percentage of standard deviation of Fitch and Margoliash $(1967)=9.089$; cophenetic correlation $N=0.986 ;$ total length of tree 0.325 .

With regard to the Balearic populations as a whole, there are 2 clusters which remain immutable: Mahon and Villacarlos (eastern Minorca), Palma Majorca and Ibiza City. For example, in the phenetic analyses using the UPGMA algorithm with the Nei distance and the strict consensus tree with the UPGMA, and SINGLE algorithms with Prevosti distance (not shown here) the populations of Minorca appear together and the Balearic population that diverges most from the rest is that of San Antonio (Ibiza). The cladogenetic analyses with Wagner's procedure 
(especially with the Cavalli-Sforza and Edwards distance) show trees with much better goodness-of-fit statistics than the trees obtained from a phenetic analysis. In all these analyses using the method of midpoint rooting of the longest path with either Cavalli-Sforza and Edwards or Prevosti distances the populations of Mahon, Villacarlos and Mercadal and Alayor (eastern and Central Minorca) differ from the rest of the Balearic populations. Ciudadela (western Minorca) clusters with the populations of San Antonio (Ibiza) while Palma Majorca and Ibiza City maintain their genetic similarity.

\section{Phenetic analysis of the 7 Balearic cat populations studied and 70 European and North-African cat populations}

The 7 Balearic cat populations on are clearly and significantly more related to the North-African and eastern Mediterranean cat populations, and to the Catalonian cat populations with possible eastern Mediterranean and North-African origin, than to western European ones (fig 3). All the phenetic analyses show the same relationships. For instance, the UPGMA phenetic analysis with the Nei distance shows that all 4 cat populations in Minorca were closely related with some North-African populations (like Constantine (Argelia), and Tunis). In all cases, Palma Majorca and Ibiza show a strong genetic similarity to certain Catalonian populations (like Barcelona and Sitges) and also with Rabat (Morocco), Athens or Samos (Greece). San Antonio (Ibiza) shows the most marked similarity with Tarragona (Catalonia) and Argolis (Greece). All the Catalonian populations also appear together with eastern Mediterranean and North-African populations. On the other hand, the Spanish Levante populations (like Alicante, Benidorm or Murcia) are in the western European cluster. A principal coordinates analysis and a principal component analysis (not shown here) also show the same kind of genetic relationships.

\section{Percentage contribution to the genetic differences classified by loci between Balearic and Spanish cat populations}

The percentage contribution to the pairwise genetic differences classified by loci and locations is shown in table $\mathrm{X}$. The following characteristics can be seen: a) the greatest contribution to the variation in the Balearic populations comes from the $t^{b}$ allele $(31.86 \%)$ with the $l$ allele in second place $(26.16 \%)$. The $a$ allele $(4.23 \%)$ is the lower contribution to the variation between Balearic populations ( $W, M$ and $c^{s}$ were not included); b) with the Spanish populations taken as a whole, the $t^{b}$ allele $(44.9 \%)$ is the most heterogeneous and the $a$ allele distribution $(5.92 \%)$ is the most homogeneous. Undoubtedly, $q\left(t^{b}\right)$ frequency is the most outstanding factor in the differentiation of these cat populations.

\section{DISCUSSION}

\section{Hardy-Weinberg equilibrium}

Generally, when $u$ and $S$ loci (Dreux, 1975) are analyzed to study Hardy-Weinberg equilibrium, we observe a good fit with the expected proportions. Different studies 


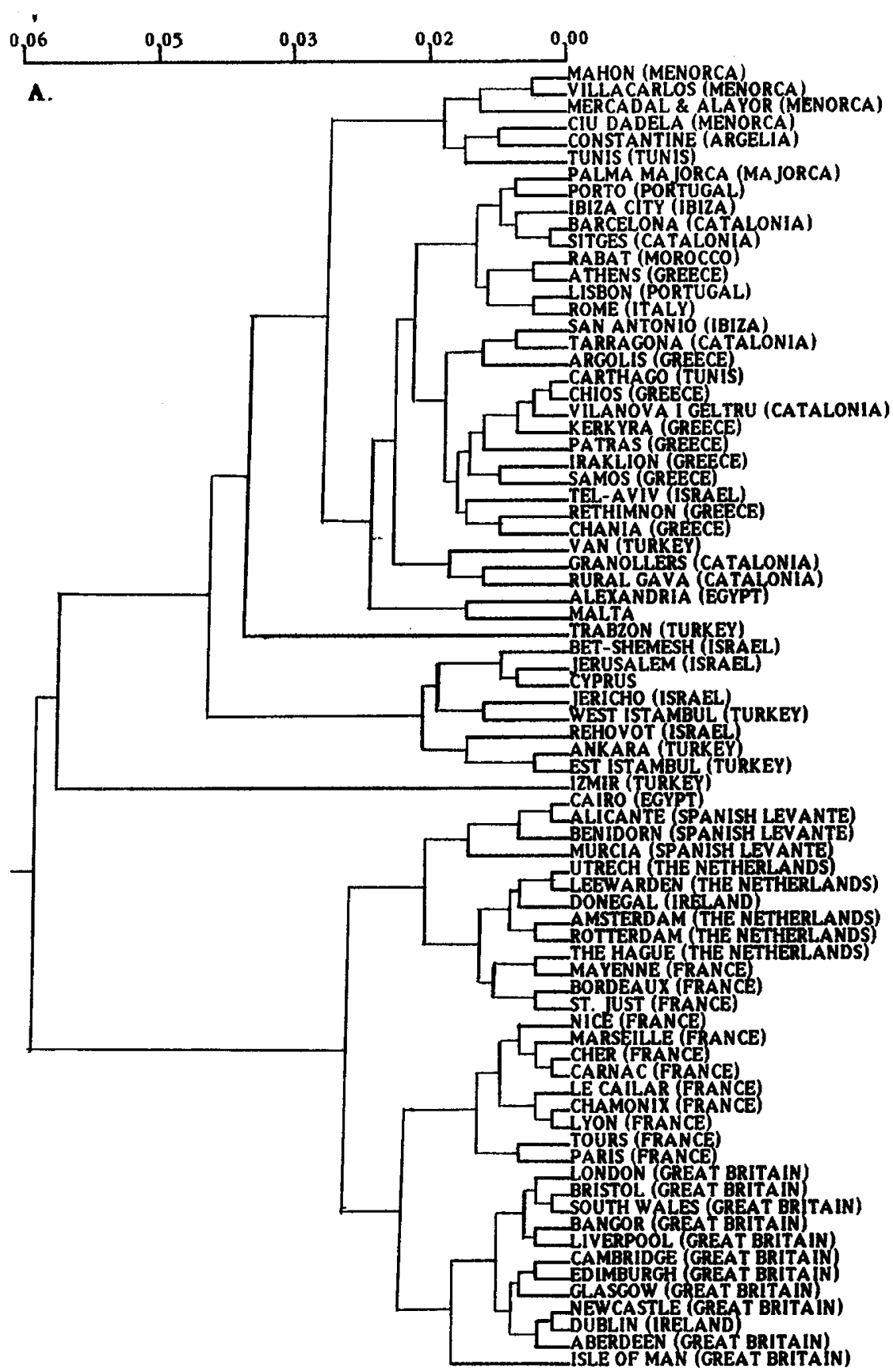

Fig 3. Phenetic analysis of European and North-African cat populations: UPGMA phenogram with Nei (1972) distance. 
Table X. (A) Contribution of individual loci to genetic differences between one population and other Balearic cat populations. The samples of Mercadal and Alayor (Minorca) and San Antonio (Ibiza) have not been included in this analysis because these samples are those which have the greatest sampling error. (B) Contribution of individual loci to genetic differences between one population and other Spanish cat populations. The allele $l$ has been not used because in some populations its value is 0 . The method which has been used is that of Adalsteinsson et al (1979) using the Kidd and Cavalli-Sforza (1974) genetic distance between pairs of populations.

\begin{tabular}{|c|c|c|c|c|c|c|c|c|}
\hline \multirow[t]{2}{*}{ Population (A) } & \multicolumn{6}{|c|}{ Contribution of each locus (\%) } & \multirow[t]{2}{*}{ Sum } & \multirow[t]{2}{*}{ Sum distance } \\
\hline & $O$ & $a$ & $t^{b}$ & $d$ & $l$ & $S$ & & \\
\hline Mahon & 2.34 & 1.73 & 4.75 & 2.08 & 3.79 & 4.65 & 19.34 & 0.14316 \\
\hline Villacarlos & 0.59 & 0.44 & 9.20 & 4.55 & 2.67 & 2.35 & 19.80 & 0.14365 \\
\hline Ciudadela & 0.83 & 0.70 & 3.25 & 1.73 & 7.94 & 2.55 & 17.00 & 0.12578 \\
\hline Palma Majorca & 1.41 & 0.90 & 9.33 & 1.73 & 8.64 & 1.51 & 23.52 & 0.17399 \\
\hline Ibiza & 0.58 & 0.46 & 5.33 & 7.15 & 3.12 & 3.69 & 20.33 & 0.15030 \\
\hline Sum & 5.75 & 4.23 & 31.86 & 17.24 & 26.16 & 14.75 & 100 & 0.73958 \\
\hline
\end{tabular}

\begin{tabular}{|c|c|c|c|c|c|c|c|}
\hline \multirow[t]{2}{*}{ Population (B) } & \multicolumn{5}{|c|}{ Contribution of each locus (\%) } & \multirow[t]{2}{*}{ Sum } & \multirow[t]{2}{*}{ Sum distance } \\
\hline & $O$ & $a$ & $t^{b}$ & $d$ & $S$ & & \\
\hline Mahon & 2.41 & 1.01 & 5.00 & 3.51 & 4.89 & 16.82 & 0.6354 \\
\hline Ciudadela & 0.45 & 0.31 & 3.14 & 2.37 & 0.75 & 7.02 & 0.2648 \\
\hline Palma Majorca & 0.48 & 0.37 & 2.49 & 2.51 & 1.10 & 6.95 & 0.2575 \\
\hline Ibiza & 0.82 & 0.32 & 1.89 & 0.94 & 0.83 & 4.80 & 0.1786 \\
\hline Barcelona (1987) & 0.97 & 0.28 & 2.35 & 0.83 & 0.98 & 5.41 & 0.2043 \\
\hline Castelldefels & 0.50 & 0.26 & 1.89 & 0.99 & 3.37 & 7.01 & 0.2648 \\
\hline Rural Gava & 0.74 & 0.92 & 5.59 & 1.26 & 0.81 & 9.32 & 0.3522 \\
\hline Sitges & 2.03 & 0.25 & 1.96 & 0.96 & 0.87 & 6.07 & 0.2293 \\
\hline Vilanova & 0.45 & 0.31 & 3.16 & 0.99 & 1.97 & 6.88 & 0.2598 \\
\hline Tarragona & 0.46 & 1.02 & 3.04 & 3.72 & 0.85 & 9.09 & 0.3440 \\
\hline Alicante & 0.60 & 0.40 & 8.63 & 0.88 & 0.99 & 11.50 & 0.4384 \\
\hline Cadiz & 0.97 & 0.47 & 5.76 & 0.83 & 1.03 & 9.06 & 0.3458 \\
\hline Sum & 10.88 & 5.92 & 44.90 & 19.79 & 18.44 & 100 & 3.7759 \\
\hline
\end{tabular}

of electrophoretic characters in cat populations have also confirmed the finding of panmixia (Hardy-Weinberg equilibrium) (Spencer, 1979; O'Brien, 1980; Ritte et al, 1980; Weghe et al, 1981; Brown and Brisbin, 1983); Futher, other felid species (like Panthera pardus, Panthera leo, Leptailurus serval, Caracal caracal, Neofelis nebulosa, Leopardus (= Felis) pardalis and Leopardus wiedi) conform also apparently to Hardy-Weinberg equilibrium (Newman et al, 1985). However, as has previously been shown, the Hardy-Weinberg equilibrium at the $O$ locus was not confirmed for the Minorca sample as a whole, nor for Ciudadela and Mercadal and Alayor because these populations apparently exhibited a significant excess of homozygotes. If these samples contained an excess of males this could provoke an apparent excess of homozygotes. Nevertheless, some of the samples were sexed and there was no significant departure from a 1:1 sex-ratio. If the disproportion of sex could be excluded as an effective explanation, the consanguinity and/or Wahlund's effect could be the causes which explain this excess of homozygotes in $O$ locus (similar 
situations have been reported for other mammals, for example, Procyon lotor, Beck and Kennedy, 1980; Oryctolagus cuniculus, Arana et al, 1989; Thomomys bottae, Daly and Patton, 1990; Cynomys ludovicianus, Chesser, 1983; Calomys laucha, Garcia et al, 1990). Selective agents are possibly not the causes of the observed situation.

\section{Genetic differentiation of the Balearic cat populations and spatial pat- terns of some variables}

The amount of genetic heterogeneity introduced by each allele is different (for example, $t^{b}$ introduces much more heterogeneity than $W, O$ or $a$ ), which indicates that the evolutionary history of each has been notably different. For example, an allele which was introduced long ago may have become highly homogeneized throughout the area in question whereas an allele which arrived more recently may present a stronger genetic heterogeneity. In short, each allele may have suffered different stochastic processes depending on the existing demographic population parameters at any historical moment. Neither can we completely rule out that the influence of diversifying or unifying selective processes (depending on the different loci which have been studied) is not necessary to explain the different amount of genetic heterogeneity introduced by each allele. The average $F_{s t}$ values and the geneflow estimates $(\mathrm{Nm})$ obtained for these Balearic cat populations are extraordinarily different from those observed for other island mammals. For example, NavajasNavarro and Britton-Davidian (1989) showed for Mus musculus, an $F_{s t}$ value of 0.278 and an $N m$ value of 0.65 for this species on the western Mediterranean islands. We may conclude that the genetic differentiation of the Balearic cat populations is relatively limited and that gene flow is substantially greater that what is observed for other island species. This strong gene flow may be due to the intrinsic ethological characteristics of the cat (Ruiz-Garcia and Klein, 1993), but, above all, this high level of gene flow is due to the association between man and cat, where the latter depends on the high mobility of the former. Nevertheless, in spite of all this, we can observe the existence of significant genetic heterogeneity for most of the studied loci. Wright (1931) stated that if $N m>1$ then gene flow is important enough to erase the genetic heterogeneity between the populations in equilibrium. In this study, we obtained $\mathrm{Nm}$ estimates of approximately 9 cats in Minorca and 6 cats in the Balearic islands as a whole. However, a significant genetic heterogeneity was observed. This might perhaps be explained by Allendorf and Phelps (1981) who argued that the most correct interpretation of $N m>1$ is that the populations share the same alleles though not necessarily with the same allele frequencies. By means of simulation models they showed that significant allele divergence occurred in $50 \%$ of the generations with a very high gene flow of $\mathrm{Nm}=50$ and that significant allele differentiation occurred on most ocassions when $N m=10$.

Cats introduced at different points of the islands may originate from diverse places (though predominantly from the Mediterranean world), with different frequencies for the alleles introduced at different points. This can be proved by the existence of significant spatial autocorrelation of a clinal kind and of differentation at maximum distance for some alleles (eg, $d, S, W$ and to a smaller extent $t^{b}$ ). 


\section{Genetic relationships between the Balearic cat populations and other European and North-African cat populations}

Although some significant genetic differentiation is observable between the Balearic cat populations, we can state that the Balearic populations which have been studied are of a clear eastern Mediterranean and North-African origin. All this is in agreement with the history of the inhabitants of Balearics. Phoenicians, Greeks, Romans and, especially, the Carthagenian hegemony from North-Africa, were present in the Balearics. The Arabian presence for 500 years in Balearics (700-1 $200 \mathrm{BC}$ ) was also very important. It is probable that these human movements in the Balearics were responsible for this genetic similarity between the Balearic cat populations and the North-African and eastern Mediterranean ones. Moreover, other historical events can help to understand the close genetic relationships between these cat populations, such as the extraordinarily strong historical and commercial relationships between Catalonia and the eastern Mediterranean (Greece, especially) and North Africa during 13th and 16th centuries. Catalonia became most important in the western Mediterranean area with direct contact with eastern Mediterranean and North-African harbours in 14th-15th centuries. Catalonia first conquered Majorca, Ibiza and Minorca. Later, Catalonia conquered Athens, Arta, Morea, Neopatria (all Greek cities) and other areas in Turkey and established consulates in Syria, North Africa, Malta and Cyprus. Important Greek cities were dominated by Catalans for 1 century (in the Attica region, the Catalans had possession until $1456 \mathrm{AD}$ ). The Catalans probably introduced an important number of cats into Balearics on their journeys to eastern Mediterranean and North-African areas during the 13th16 th centuries. If these Balearic cat populations were much younger (for example, if they were founded during the last 2 centuries) they might have these eastern Mediterranean and North-African genetic characteristics because they might stem indirectly from populations of eastern Mediterranean origin like the present Catalan populations.

\section{Might there be any correlation between the introduction of the cat on the Balearic islands and the origin of other mammals on these islands?}

Some Balearic species of mammals like the garden dormouse (Eliomys quercinus) (at least the population of Minorca and a part of the population of Majorca; Kahmann and Tiefenbacher, 1969; Kahmann and Thoms, 1973; Kahmann and Alcover, 1974), and the pine marten (Martes martes) or Mus musculus domesticus in Majorca (Navajas y Navarro and Britton-Davidian, 1989) might be of western European origin. However, the introduction of other mammals to these islands might be in correlation with the introduction of the cat. Some Balearic species of mammals which might turn out to be of North-African and Eastern origin are: the Balearic hedgehog (Aetechinus algirus) classified by Thomas (1901) as a NorthAfrican species; the rabbit (Oryctolagus cuniculus) introduced into North-Africa by the Phoenicians according to Petter and Saint-Girons (1972) and possibly also into the Balearic islands; and the black rat (Rattus rattus frugivorus) introduced by the Catalans or by the Arabs according to Alcover (1979). Boursot et al (1985) showed the relationship of mitochondrial forms between the Mus spretus populations of Ibiza and Tunisia. Frechkop (1963) stated that the weasel in Majorca was Mustela 
numidica, that is, the North-African species. Another carnivore like Genetta genetta was undoubtedly introduced into the Balearic islands by the Arabs. These authors have shown the North-African and eastern origin of these mammals using biometric, osteological and cytological methods. In the present study, we show, for the first time, the possible eastern Mediterranean and North-African origin of the cat introduced into Balearics, using population genetics methods.

\section{ACKNOWLEDGMENTS}

The author sincerely thanks HF Hoenigsberg (Bogota, DC Colombia), A Sanjuan (Vigo, Spain), KK Klein (Minnesota, USA), AT Lloyd (Dublin, Ireland), PH Dreux (Paris, France), R Robinson (London, Great Britain), the referees for their respective comments, and especially D Alvarez (Bogota, DC Colombia) for her magnificent assistance.

\section{REFERENCES}

Adalsteinsson S, Sigurjonsson T, Jonsson G (1979) Variation in colour gene frequencies among Icelandic cats. Carniv Genet News 3, 359-372

Ahmad M, Blumenberg B, Chaudhary MJ (1980) Mutant allele frequencies and genetic distance in cat populations of Pakistan and Asia. J Hered 71, 323-330

Alcover.JA (1979) Els Mamífers de les Balears Editorial Moll. Palma de Mallorca Allendorf FW, Phelps SR, (1981) Use of allelic frequencies to describe population structure. Can J Fish Aquat Sci, 38, 1507-1514

Arana A, Zaragoza P, Rodellar C, Amorena B (1989) Blood biochemical polymorphisms as markers for genetic characteristics of Wild Spanish and domestic rabbits. Genetica 79, 1-9

Beck ML, Kennedy ML (1980) Biochemical genetics of the raccon, Procyon lotor. Genetica 54, 127-132

Blumenberg B (1977) Genetic difference and selection in domestic cat populations of the United Kingdom and former British colonies. Theor Appl Gene 49, 243-247 Blumenberg B, Lloyd AT (1980) Mutant allele frequencies in the domestic cat: a preliminary discussion of selection with particular reference to the United Kingdom and Eire. Genetica 54, 17-28

Boursot P, Jacquart T, Bonhomme F, Britton-Davidian J, Thaler L (1985) Differenciation géographique du génome mitochondrial chez Mus spretus, Lataste. CR Acad Sci Ser III, 301, 5, 161-166

Brown CJ, Brisbin IL (1983) Genetic analysis of pariah cat populations from the Southern United States. J Hered 74, 344-348

Cavalli-Sforza LL, Edwards AWF (1967) Phylogenetic analysis: models and estimation procedures. Evolution 21, 550-570

Chesser RK (1983) Genetic variability within and among populations of the blacktailed prairie dog. Evolution 37, 320-331

Committee on Standardized Genetic Nomenclature for Cat (1968) Standardized genetic nomenclature for the domestic cat. $J$ Hered 59, 39-40

Crow JF, Aoki K (1984) Group selection for a polygenic behavioural trait: Estimating the degree of population subdivision. Proc Natl Acad Sci USA 81, 6073-6077 
Daly JC, Patton JL (1990) Dispersal gene flow, and allele diversity between local populations of Thomomys bottae pocket gophers in the coastal ranges of California. Evolution 44, 1283-1294

Dreux P (1975) Génétique de population des chats domestiques de Marseille (Bouches-du-Rhône, France). Ann Genet Sel Anim, 7, 23-33

Dunn G, Everitt S (1982) An Introduction to Mathematical Taxonomy. 152 pp. Camb Univ Press, UK

Farris JS (1972) Estimating phylogenetic trees from distance matrices. Am Nat 106, 645-668

Fitch WM, Margoliash E (1967) Construction of phylogenetic trees. Science 155, 279-284

Frechkop S (1963) Notes sur les Mammifères. L. De la Boccamele de Sardaigne. Bull Inst R Sci Nat Belg Biol 39, 1-21

Garcia BA, Gardenal CN, Blanco A (1990) Heterozygosity and gene flow in populations of Calomys laucha (Rodentia, Cricetidae). Hereditas 112, 179-186

Hollander M, Wolfe DA (1973) Non-parametric Statistical Methods. John Wiley, New York

Hubert H, Golledge RG (1982) Measuring association between spatially defined variables: Tjostheim's index and some extensions. Geogr Anal 14, 273-278

Hubert LH, Golledge RG, Costanzo CM (1981) Generalized procedures for evaluating spatial autocorrelation. Geogr Anal 13, 224-233

Kahmann H, Alcover JA (1974) Sobre la binomia del Liron Careto (Eliomys quercinus L) en Mallorca (Baleares). Boll Soc Hist Nat Baleares 19, 57-74

Kahmann H, Tiefenbacher L (1969) Der Gartenschläfer Eliomys quercinus (Linné, 1766) der Baleareninsel Minorca. Säugetierkundl Mitt 17, 242-247

Kahmann H, Thoms G (1973) Der Gartenschläfer (Eliomys) Minorcas. Saugetierkundl Mitt 21, 65-73

Kidd KK, Cavalli-Sforza LL (1974) The role of genetic drift in the differentiation of Icelandic and Norwegian cattle. Evolution 28, 381-395

Kimura M (1983) The Neutral Theory of Molecular Evolution. Camb Univ Press, UK

Kimura M, Weiss GH (1964) The stepping stone model of population structure and the decrease of genetic correlation with distance. Genetics 49, 561-576

Klein KK, Smith S, Schmidt J, Shostak J, Kerr SJ (1988) Mutant allele frequencies in Upper Midwestern cat populations in the United States. $J$ Hered 79, 389-393

Lilliefors HW (1967) On the Kolmogorov-Smirnov test for normality with mean and variance unknow. Amer Stat J 62, 399-402

Llloyd AT (1985) Geographic distribution of mutant allele in domestic cat populations of New England and the Canadian Maritimes. J Biogeog 12, 315-322

Lloyd AT, Todd NB (1989) Domestic Cat Gene Frequencies. A Catalogue and Bibliography. Tetrahedron Publications. Newcastle upon Tyne, UK

Mantel NA (1967) The detection of disease clustering and a generalized regression approach. Canc Res 27, 209-220

Navajas y Navarro M, Britton-Davidian J (1989) Genetic Structure of insular Mediterranean populations of the house mouse. Biol J L Soc 36, 377-390

Nei M (1972) Genetic distance between populations. Amer Nat 106, 283-292 
Nei M (1978) Estimation of average heterozygosity and genetic distance from a small number of individuals. Genetics $89,583-590$

Nei M, Tajima F, Tateno Y (1983) Accuracy of estimated phylogenetic trees from molecular data. Gene frequency data. J Mol Evol 19, 153-170

Nei M, Imaizumi Y (1966) Genetic structure of human populations. II. Differentiation of blood group gene frequencies among isolated population. Heredity 21, 461-472

Newman A, Bush M, Wildt DE, Van Dam D, Frankenhuis MT, Simmons L, Phillips L, O'Brien SJ (1985) Biochemical genetic variation in eight endangered or threatened felid species. J Mammal 66, 256-267

O'Brien SJ (1980) The extent and character of biochemical genetic variation in the domestic cat. $J$ Hered $71,2-8$

Oden N (1984) Assessing the significance of a spatial correlogram. Geogr Anal 16, 1-16

Petter F, Saint-Girons MC (1972) Les Lagomorphes du Maroc. Bull Soc Sci Nat Phys Maroc 52, 121-129

Prager EM, Wilson AC (1976) Congruency of phylogenies derived from different proteins. A molecular analysis of the phylogenetic position of cracid birds. $J \mathrm{Mol}$ Evol 9, 45-57

Prevosti A (1974) La distancia genética entre poblaciones. Miscellanea Alcobé. Publicacions Universitat de Barcelona, 109-118

Prevosti A, Ocaña J, Alonso G (1975) Distances between populations of Drosophila subobscura based on chromosoma arrangements frequencies. Theor Appl Genet 45, 231-241

Ritte U, Cohen T, Neufeld E, Saliternik-Vardy R (1980) Electrophoretic variation in blood proteins of the domestic cat. Carn Genet Newsl 4, 98-107

Robinsons R (1972) Mutant gene frequencies in cats of Cyprus. Theor Appl Genet 42, 293-296

Robinson R (1977) Genetics for Cat Breeders. Pergamon Press, Oxford, UK

Robinson R, Manchenko GP (1981) Cat gene frequencies in cities of the USSR. Genetica 55, 41-46

Rohlf FJ (1982) Consensus indices for comparing classifications. Math Biosci 59, 131-144

Ruiz-Garcia M (1988) Frecuencias alélicas mutantes en una población de gatos domésticos urbanos (Barcelona) y en una población de gatos rurales (Castelldefels rural) en Cataluña, España. Genética Ibérica 40, 157-187

Ruiz-Garcia M (1990a) Mutant allele frequencies in domestic cat populations in Catalonia, Spain, and their genetic relationships with Spanish and English colonial cat populations. Genetica $82,209-214$

Ruiz-Garcia M (1990b) Mutant allele frequencies in domestic cat populations on the Spanish Mediterranean Coast, and their genetic distances from other European and North-African cat populations. Genetica 82, 215-221

Ruiz-Garcia M (1990c) Frecuencias alélicas en la población de gatos domésticos de la isla de Minorca (Baleares): Diferentes Modelos de Evolución Colonizadora. Evol Biol 4, 307-342 
Ruiz-Garcia M, Klein KK (1993) Genetic structure of domestic cat populations (Felis catus) at Micro and Macrogeographical levels: Two Examples (Catalonia, Spain and Upper Mid-Western USA). J Hered submitted

Sarria A, Guardia J , Freixa M (1987) Introducción a la estadística en Psicologia. Ed Alamex. Barcelona, Spain

Scribner KT, Smith MH, Garrot RA, Carpentier LH (1991) Temporal, spatial, and age-specific changes in genotypic composition of mule deer. J Mammal 72, 126-137 Searle AG (1949) Gene Frequencies in London's Cats. J Genet 49, 214-220

Simpson GG, Roe A, Lewontin RC (1960) Quantitative Zoology. Harcourt Brace, New York

Slatkin M (1985) Rare alleles as indicators of gene flow. Evolution 39, 53-65 Smouse PE, Long JC, Sokal RR (1986) Multiple regression and correlation extensions of the Mantel test of matrix correspondence. Syst Zool 35, 627-632 Sneath PH, Sokal RR (1973) Numerical Taxonomy. Freeman. San Francisco Sokal RR, Oden NL (1978a) Spatial autocorrelation in biology. 1. Methodology. Biol J Linn Soc 10, 199-228

Sokal RR, Oden NL (1987b) Spatial autocorrelation in biology. 2. Some biological implications and four applications of evolutionary and ecological interest. Biol $J$ Linn Soc 10, 229-249

Sokal RR, Rohlf FJ (1981) Biometry (WH Freeman, ed), San Francisco

Sokal RR, Wartenberg DE (1983) A test of spatial autocorrelation using an isolation-by-distance model. Genetics, 105, 219-237

Spencer N (1979) Genetics of cat haemoglobins: a quantitative polymorphism. Biochem Genet 17, 747-756

Swofford DL (1981) On the utility of the distance Wanger procedure. In: Advances in Cladistic: Proceedings of the First Meeting of the Willie Hennig Society. (VA Funk and DR Brooks, eds), New York Botanical Garden, Bronx, New York, 25-43 Takahata N (1983) Gene identity and genetic differentiation of populations in the finite island model. Genetics 104, 497-512

Thomas O (1901) On the mammals of the Balearic Islands. Proc Zool Soc London $1,35-44$

Weghe A, Bouquet Y, Mattheeuws D, Zeveren A (1981) Polymorphism in blood substances of the cat. Comp Biochem Physiol 69, 223-230

Workman PL, Niswander JD (1970) Population studies on south-western Indian tribes. II. Local genetic differentiation in the Papago. Amer J Human Genet 22, 24-49

Wright S (1931) Evolution in Mendelian populations. Genetics 16, 97-159

Wright S (1943) Isolation by distance. Genetics 28, 114-138

Wright S (1969) Evolution and the Genetics of Populations. Vol 2. The Theory of Gene Frequency. Univ Chicago Press. Chicago

Wright S (1978) Evolution and the Genetics of Populations. Vol 4. Variability within and among Natural Populatons. Univ Chicago Press. Chicago

Wright M, Walters S (1982) El gato. Ed Blume. Barcelona, Spain 